Article

\title{
Low pressure one-pot synthesis of dimethyl carbonate catalyzed by an alkali carbonate
}

\author{
Chun Liu*, Shaoke Zhang, Baoyi Cai, Zilin Jin \\ State Key Laboratory of Fine Chemicals, Dalian University of Technology, Dalian 116024, Liaoning, China
}

\section{A R T I C L E I N F O}

Article history:

Received 7 January 2015

Accepted 29 January 2015

Published 20 July 2015

\section{Keywords:}

Dimethyl carbonate

Epoxide

Alkali carbonate

One-pot synthesis

Low pressure

\section{A B S T R A C T}

A mild and efficient protocol for the alkali carbonate-catalyzed one-pot synthesis of dimethyl carbonate (DMC) from epoxide, $\mathrm{CO}_{2}$ and methanol was developed. The reaction conditions for the one-pot synthesis of DMC were investigated. Under the optimized conditions of initial pressure 0.5 MPa, $120{ }^{\circ} \mathrm{C}$ and catalyst loading of $7.5 \mathrm{~mol} \%, 63.5 \%$ yield of DMC was achieved using ethylene oxide as the starting material. A mechanism for the catalysis by the alkali carbonate was proposed.

(C) 2015, Dalian Institute of Chemical Physics, Chinese Academy of Sciences. Published by Elsevier B.V. All rights reserved.

\section{Introduction}

Global warming is of great concern as it can lead to alterations to the climate. For example, the rainfall distribution can change and the frequency of severe weather events, such as hurricanes and typhoons, can increase [1]. It is now well established that the release of $\mathrm{CO}_{2}$ from anthropogenic activities such as fossil fuel burning is among the leading causes of global warming [2,3]. Therefore, considerable efforts have been directed towards the development of technologies for $\mathrm{CO}_{2}$ activation and use [4,5], $\mathrm{CO}_{2}$ capture [6,7], and the conversion of $\mathrm{CO}_{2}$ to useful substances [8-12]. One of the most promising utilization of $\mathrm{CO}_{2}$ is the synthesis of dimethyl carbonate (DMC). DMC is an environmentally benign substitute for toxic dimethyl sulfate, methyl iodide, and phosgene. DMC can also be used for the synthesis of polycarbonate resins, as a green solvent, as a capture agent for $\mathrm{CO}_{2}$, and as a gasoline additive to increase octane number $[13,14]$.
DMC was produced from methanol and phosgene for the first time in the 1910s, but this process was eliminated in recent years due to the use of the virulent phosgene [15]. There are now three other routes for the production of DMC. The first is the oxidative carbonylation of methanol using $\mathrm{CuCl}$ as catalyst. Its main drawback is the production of corrosive hydrogen chloride [16]. The second is the carbonylation of methyl nitrite over Pd/carbon. Here, the use of toxic $\mathrm{CO}$ is the main problem [17]. The third is the transesterification method in which a cyclic carbonate is formed first from an epoxide and $\mathrm{CO}_{2}$, and subsequently a transesterification follows to produce DMC [18]. In recent years, other novel processes have been developed for the synthesis of DMC, such as the direct synthesis of DMC from $\mathrm{CO}_{2}$ and methanol [19], the "one-pot, two-step" method [20], and the one-pot synthesis [21]. Among these, the one-pot synthesis of DMC from $\mathrm{CO}_{2}$, epoxide and methanol (Scheme 1) is a simple and economic approach for the synthesis of DMC. However, a side reaction occurs due to the addition

\footnotetext{
* Corresponding author. Tel: +86-411-84986182; E-mail: cliu@dlut.edu.cn This work was supported by the Fundamental Research Funds for the Central Universities (DUT15ZD107). 


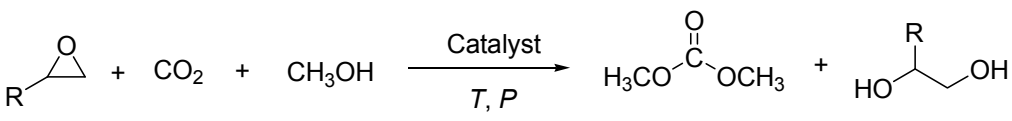

$$
\begin{aligned}
& \stackrel{\mathrm{O}}{\mathrm{O}}+\mathrm{CH}_{3} \mathrm{OH} \longrightarrow \mathrm{H}_{3} \mathrm{CO} \stackrel{\mathrm{R}}{\mathrm{OH}}+{ }_{\mathrm{HO}}^{\mathrm{R}} \mathrm{OCH}_{3}
\end{aligned}
$$

Scheme 1. One-pot synthesis of DMC (1) and its side reaction (2).

of methanol [21].

There are several reports on the one-pot synthesis of DMC using different catalysts [21-36]. Among these, alkali carbonates have attracted attention due to its cheapness, negligible eco-toxicity and basic properties. In 2001, Bhanage et al. [36] reported that $8.7 \%$ yield of DMC was obtained in $15 \mathrm{~h}$ from propylene oxide (PO) using $24.8 \mathrm{~mol}_{\%} \mathrm{~K}_{2} \mathrm{CO}_{3}$ as catalyst at 150 ${ }^{\circ} \mathrm{C}$ under $8 \mathrm{MPa} \mathrm{CO}_{2}$. In 2003, Cui et al. [35] achieved 51.5\% yield of DMC in $3 \mathrm{~h}$ from ethylene oxide (EO) using $15.9 \mathrm{~mol} \%$ $\mathrm{K}_{2} \mathrm{CO}_{3}$ as catalyst at $120{ }^{\circ} \mathrm{C}$ under $15 \mathrm{MPa} \mathrm{CO}_{2}$. Very recently, Yang et al. [23] obtained 38.7\% yield of DMC after $6 \mathrm{~h}$ from cyclohexane oxide ( $\mathrm{CHO}$ ) using $0.8 \mathrm{~mol} \% \mathrm{~K}_{2} \mathrm{CO}_{3}$ as catalyst at $150{ }^{\circ} \mathrm{C}$ under $2.6 \mathrm{MPa} \mathrm{CO}_{2}$ (initial pressure at room temperature). It is clear from these results that a high reaction pressure is needed in the one-pot synthesis of DMC catalyzed by an alkali carbonate, and the highest yield of DMC was 50\%. The one-pot synthesis of DMC under an initial pressure less than 2.0 $\mathrm{MPa}$ has not been reported. In this paper, we describe an efficient protocol for the direct synthesis of DMC under a low pressure from $\mathrm{CO}_{2}$, epoxide and methanol catalyzed by alkali carbonate.

\section{Experimental}

\subsection{Materials}

Propylene oxide, cyclohexene oxide, styrene oxide, epichlorohydrin and glycidyl phenyl ether were purchased from Sinopharm Chemical Reagent Co., Ltd. Ethylene oxide was a gift from Liaoning Oxiranchem Co., Ltd. $\mathrm{CO}_{2}$ was purchased from Dalian Guangming Special Gas Co., Ltd. The other chemicals were obtained commercially and used without any prior purification.

\subsection{General procedure for the one-pot synthesis of DMC}

The one-pot synthesis of DMC was carried out in a stainless steel autoclave reactor with a volume of $75 \mathrm{ml}$. A typical procedure was as follows: epoxide (14.3 mmol), methanol (214.5 mmol, $8.7 \mathrm{~mL}$ ), $\mathrm{Na}_{2} \mathrm{CO}_{3}$ (5.0 mol\%) and biphenyl (80 mg, an internal standard for GC analysis) were charged in the autoclave at room temperature. Then $\mathrm{CO}_{2}$ was introduced into the reactor, which was heated to $120{ }^{\circ} \mathrm{C}$ for $6 \mathrm{~h}$. After cooling, the reaction mixture was analyzed by gas chromatograph.

\subsection{Techniques used}

GC analysis was recorded on a gas chromatograph (Agilent 7820) equipped with a capillary column (HP-5, $30 \mathrm{~m} \times 320 \mu \mathrm{m} \times$ $0.25 \mu \mathrm{m}$ ) using a flame ionization detector with a flow rate of 1
$\mathrm{mL} / \mathrm{min}$. The following parameters were used: oven temperature was held at $50{ }^{\circ} \mathrm{C}$ for $5 \mathrm{~min}$ and then increased linearly to $240{ }^{\circ} \mathrm{C}$ over $20 \mathrm{~min}$ with a final hold of $5 \mathrm{~min}$.

\section{Results and discussion}

Due to the similar properties of 1-methoxy-2-propanol (1-ME-2-PA) and 2-methoxy-1-propanol (2-ME-1-PA), PM is used in this paper to represent both 1-ME-2-PA and 2-ME-1-PA. Propylene carbonate is abbreviated as $\mathrm{PC}$, and 1,2-propanediol is abbreviated as PG.

\subsection{The effect of the catalyst on the one-pot synthesis of DMC}

The reaction of propylene oxide (PO), methanol and $\mathrm{CO}_{2}$ was chosen as a model reaction to screen the catalysts under the conditions of $0.5 \mathrm{MPa}, 120^{\circ} \mathrm{C}, 6 \mathrm{~h}$. The results are summarized in Table 1. No DMC was detected and a high yield of PM byproduct was obtained in the absence of a catalyst (Table 1, entry 1). More than $69.0 \%$ conversion of PO was obtained in the presence of different catalysts, and the yield of DMC varied from $2.0 \%$ to $44.5 \%$. This showed that the catalyst was crucial to both the cyclo-addition of $\mathrm{PO}$ and the transesterification of PC. An organic base $(i-\mathrm{Pr})_{2} \mathrm{NH}$ was relatively ineffective in the catalytic system for the synthesis of DMC (Table 1, entry 2). A high yield of PC and a low yield of PM were obtained in the

Table 1

Catalyst screening for the one-pot synthesis of DMC.

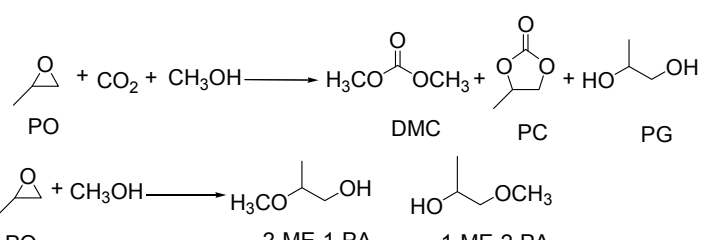

PO 2-ME-1-PA 1-ME-2-PA

\begin{tabular}{lcccccr}
\hline \multirow{2}{*}{ Entry } & \multirow{2}{*}{ Catalyst } & Conversion of & \multicolumn{4}{c}{ Yield b $^{\mathrm{b}}(\%)$} \\
\cline { 4 - 7 } & & $\mathrm{PO}^{\mathrm{a}}(\%)$ & $\mathrm{DMC}$ & \multicolumn{1}{c}{$\mathrm{PC}$} & $\mathrm{PG}$ & $\mathrm{PM}$ \\
\hline 1 & $\mathrm{None}$ & 54.3 & 0 & 0.7 & 0 & 53.6 \\
2 & $(i-\mathrm{Pr})_{2} \mathrm{NH}$ & 69.1 & 2.0 & 16.9 & 3.2 & 50.2 \\
3 & $\mathrm{KI}$ & 87.5 & 3.1 & 82.7 & 3.7 & 1.7 \\
4 & $\mathrm{TBAI}$ & 94.8 & 9.3 & 82.1 & 10.5 & 3.4 \\
5 & $\mathrm{NaH}$ & 77.4 & 6.7 & 20.1 & 7.5 & 50.6 \\
6 & $\mathrm{CH}_{3} \mathrm{ONa}$ & 82.0 & 21.3 & 19.4 & 23.6 & 41.3 \\
7 & $\mathrm{NaOH}$ & 88.4 & 29.8 & 16.6 & 28.2 & 42.0 \\
8 & $\mathrm{Na}_{2} \mathrm{CO}_{3}$ & 87.9 & 43.0 & 18.5 & 42.7 & 26.4 \\
9 & $\mathrm{~K}_{2} \mathrm{CO}_{3}$ & 88.2 & 42.7 & 15.6 & 40.4 & 29.9 \\
\hline
\end{tabular}

Reaction conditions: PO (1 mL, $14.3 \mathrm{mmol}), \mathrm{CH}_{3} \mathrm{OH}(8.7 \mathrm{~mL}, 214.4$ mmol), catalyst (5.0 mol\%), initial pressure $0.5 \mathrm{MPa}, 120^{\circ} \mathrm{C}, 6 \mathrm{~h}$.

a Sum of the yields of DMC, PC and PM.

${ }^{b}$ Average of two runs, determined by GC using an internal standard technique. 
presence of KI or TBAI (Table 1, entries 3 and 4), which demonstrated that KI and TBAI efficiently catalyzed the cyclo-addition of $\mathrm{PO}$ with $\mathrm{CO}_{2}$ and decreased the alcoholysis of PO. $\mathrm{NaH}, \mathrm{NaOH}$ and $\mathrm{CH}_{3} \mathrm{ONa}$ gave yields of DMC less than $30 \%$, and a high yield of PM was obtained (Table 1, entries 5-7). Although $\mathrm{NaOH}$ and $\mathrm{CH}_{3} \mathrm{ONa}$ are stronger alkalis than the other catalysts used, they were less effective for the formation of DMC compared to $\mathrm{Na}_{2} \mathrm{CO}_{3}$ and $\mathrm{K}_{2} \mathrm{CO}_{3}$ (Table 1, entries 6 and 7 versus 8 and 9). The reason for this may be that high alkalinity catalysts have a high activity for the alcoholysis of PO [37]. This indicated that a catalyst with suitable alkalinity was essential to the efficient synthesis of DMC. We chose $\mathrm{Na}_{2} \mathrm{CO}_{3}$ as the catalyst for further research.

\subsection{The effect of pressure on the synthesis of DMC}

The effect of pressure on the one-pot synthesis of DMC was tested using the same model reaction in the presence of 5.0 mol\% $\mathrm{Na}_{2} \mathrm{CO}_{3}$ under the conditions of $120^{\circ} \mathrm{C}$ and $6 \mathrm{~h}$. The experimental results are shown in Fig. 1. Higher than 77.5\% PO conversion was obtained with an initial pressure range of 0 to 3.5 $\mathrm{MPa}$, and lower than $74.5 \%$ PO conversion were obtained with an initial pressure range of 4.0 to $5.5 \mathrm{MPa}$. The yields of DMC and PG reached $43.0 \%$ and $42.7 \%$, respectively, with an initial pressure of $0.5 \mathrm{MPa}$ and decreased with the increase of initial pressure from 0.5 to $3.5 \mathrm{MPa}$. Further increasing of the initial pressure resulted in a slight increase in the yield of DMC. In the whole initial pressure range from 0 to $5.5 \mathrm{MPa}$, the yield of $\mathrm{PM}$ reached a maximum in the absence of $\mathrm{CO}_{2}$ and remained roughly constant with an initial pressure higher than $0.5 \mathrm{MPa}$. It is clear from Fig. 1 that the conversion of $\mathrm{PO}$ and the yields of DMC, PC and PG changed when the initial pressure was increased from 3.5 to $4.0 \mathrm{MPa}$, and the yield of DMC reached $25.0 \%$ with an initial pressure higher than $4.5 \mathrm{MPa}$. The reason for this may be that the reaction mixture is in the supercritical

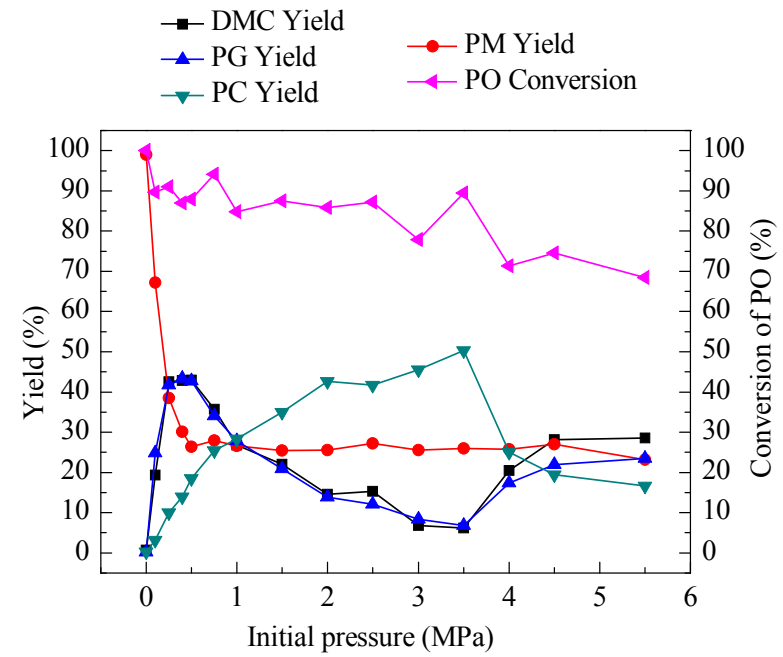

Fig. 1. Effect of pressure on the synthesis of DMC in the presence of 5.0 mol\% $\mathrm{Na}_{2} \mathrm{CO}_{3}$. Reaction conditions: $\mathrm{PO}$ (1.0 mL, $14.3 \mathrm{mmol}$ ), $\mathrm{CH}_{3} \mathrm{OH}$ (8.7 $\mathrm{mL}, 214.4 \mathrm{mmol}$ ), $\mathrm{Na}_{2} \mathrm{CO}_{3}(75.7 \mathrm{mg}, 5.0 \mathrm{~mol} \%), 120^{\circ} \mathrm{C}, 6 \mathrm{~h}$. Yields and conversions are the average of two runs determined by GC using an internal standard technique. state when the reaction pressure is higher than 7.8 MPa (initial pressure of $4.0 \mathrm{MPa}$ ) at $120{ }^{\circ} \mathrm{C}$, which is in accordance with previous reports $[31,33,35]$. With further increasing of the loading of $\mathrm{Na}_{2} \mathrm{CO}_{3}$ to $7.5 \mathrm{~mol} \%$, a similar effect of the pressure on both the yields of products and the conversion of PO was observed (Fig. 2). The results in Fig. 1 and Fig. 2 demonstrated that the optimal initial pressure for the one-pot synthesis of DMC catalyzed by $\mathrm{Na}_{2} \mathrm{CO}_{3}$ was $0.5 \mathrm{MPa}$ (reaction pressure, 1.0 $\mathrm{MPa}$ ). A higher pressure is unfavorable for both the conversion of $\mathrm{PO}$ and yield of DMC.

\subsection{The effect of temperature on the synthesis of DMC}

The effect of reaction temperature on the one-pot synthesis of DMC was investigated using the same model reaction in the presence of $5.0 \mathrm{~mol} \% \mathrm{Na}_{2} \mathrm{CO}_{3}$ under the conditions of initial pressure $0.5 \mathrm{MPa}$ and $6 \mathrm{~h}$. The results are shown in Fig. 3. A slight effect of the reaction temperature on PO conversion was observed, and higher than $86.5 \%$ conversions were obtained at temperatures from 110 to $150{ }^{\circ} \mathrm{C}$. The yields of DMC and PG increased to $43.0 \%$ and $42.7 \%$, respectively, at $120{ }^{\circ} \mathrm{C}$ and remained roughly constant at higher temperatures. From the effects of temperature on both the yields of PC and PM, we chose $120^{\circ} \mathrm{C}$ as the optimal reaction temperature.

\subsection{The effect of reaction time on the synthesis of DMC}

The effect of reaction time on the one-pot synthesis of DMC was tested using the same model reaction in the presence of 5.0 mol\% $\mathrm{Na}_{2} \mathrm{CO}_{3}$ and the conditions of $120{ }^{\circ} \mathrm{C}$ and initial pressure $0.5 \mathrm{MPa}$. The reaction time in the range of 2 to $8 \mathrm{~h}$ was investigated. The results are shown in Fig. 4. The PO conversion was $67.3 \%$ after $2 \mathrm{~h}$ and reached $88.1 \%$ in $4 \mathrm{~h}$ and remained roughly constant with extended reaction time. The yields of DMC and PG increased with extended reaction time and re-

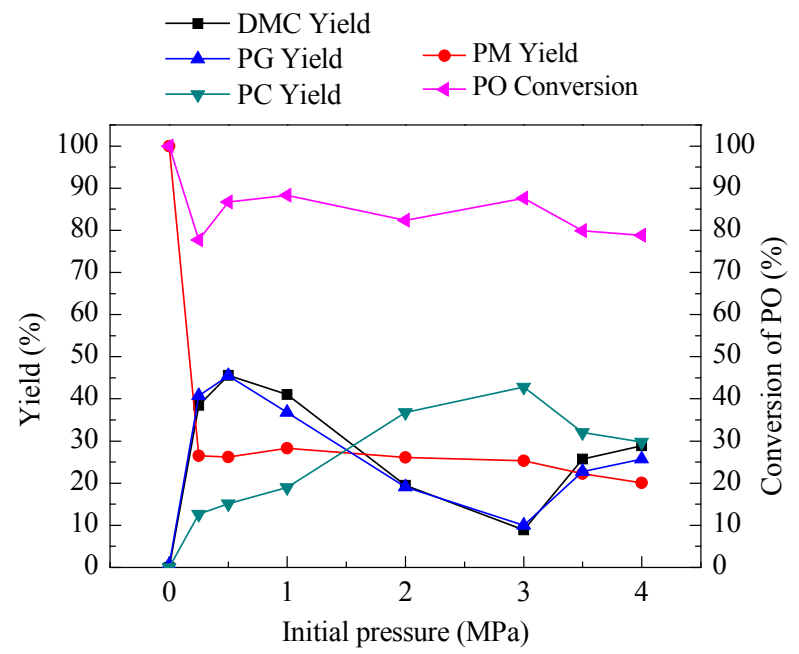

Fig. 2. Effect of pressure on the synthesis of DMC in the presence of 7.5 mol\% $\mathrm{Na}_{2} \mathrm{CO}_{3}$. Reaction conditions: $\mathrm{PO}(1.0 \mathrm{~mL}, 14.3 \mathrm{mmol}), \mathrm{CH}_{3} \mathrm{OH}$ (8.7 $\mathrm{mL}, 214.4 \mathrm{mmol}$ ), $\mathrm{Na}_{2} \mathrm{CO}_{3}$ (113.6 mg, $7.5 \mathrm{~mol} \%$ ), $120{ }^{\circ} \mathrm{C}, 6 \mathrm{~h}$. Yields and conversions are the average of two runs determined by GC using an internal standard technique. 


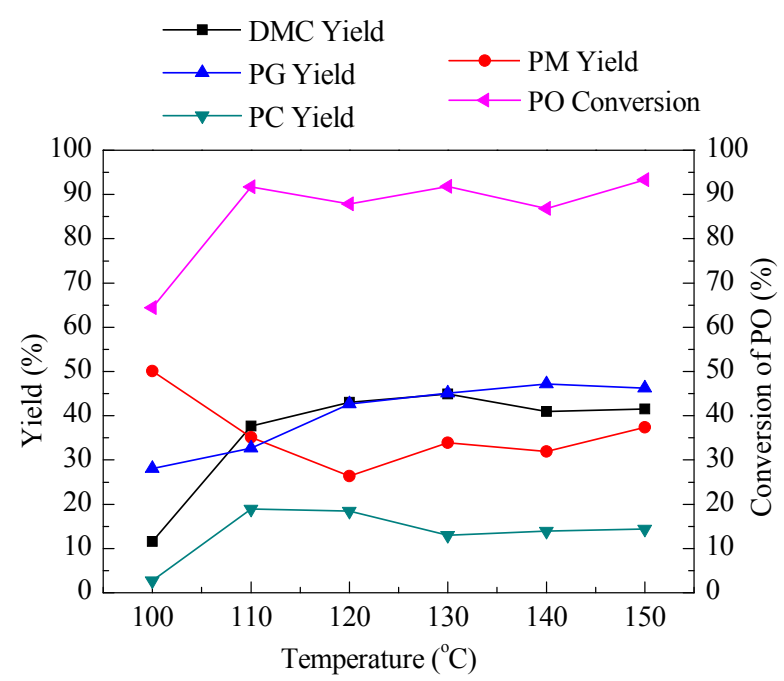

Fig. 3. Effect of temperature on the synthesis of DMC. Reaction conditions: $\mathrm{PO}(1 \mathrm{~mL}, 14.3 \mathrm{mmol}), \mathrm{CH}_{3} \mathrm{OH}(8.7 \mathrm{~mL}, 214.4 \mathrm{mmol}), \mathrm{Na}_{2} \mathrm{CO}_{3}$ (75.7 mg, $5.0 \mathrm{~mol} \%$ ), initial pressure $0.5 \mathrm{MPa}, 6 \mathrm{~h}$. Yields and conversions are the average of two runs determined by GC using an internal standard technique.

mained roughly constant at $43.0 \%$ and $42.7 \%$, respectively, after $6 \mathrm{~h}$. The yield of PC decreased with extended reaction time and remained roughly constant at $15.4 \%$ after $4 \mathrm{~h}$. A slight effect of reaction time on the PM yield was observed. A reaction time of $6 \mathrm{~h}$ was suitable for further studies.

\subsection{The effect of $\mathrm{Na}_{2} \mathrm{CO}_{3}$ loading on the synthesis of $\mathrm{DMC}$}

The effect of $\mathrm{Na}_{2} \mathrm{CO}_{3}$ loading on the one-pot synthesis of DMC was tested using the same model reaction and the conditions of initial pressure $0.5 \mathrm{MPa}, 120^{\circ} \mathrm{C}$ and $6 \mathrm{~h}$. The results are shown in Fig. 5. 54.3\% PO conversion was obtained in the absence of $\mathrm{Na}_{2} \mathrm{CO}_{3}$ and higher than $80.0 \%$ conversions were ob-

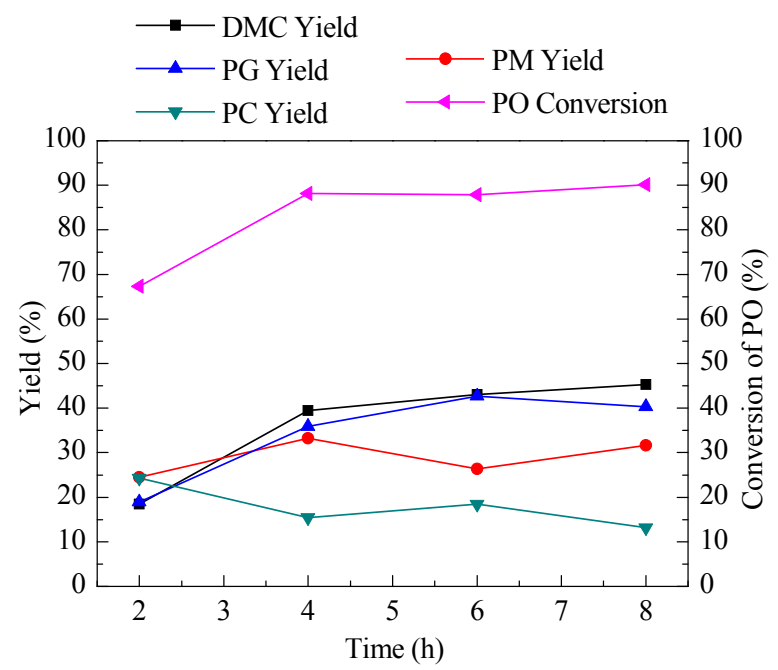

Fig. 4. Effect of reaction time on the synthesis of DMC. Reaction conditions: $\mathrm{PO}(1 \mathrm{~mL}, 14.3 \mathrm{mmol}), \mathrm{CH}_{3} \mathrm{OH}(8.7 \mathrm{~mL}, 214.4 \mathrm{mmol}), \mathrm{Na}_{2} \mathrm{CO}_{3}$ (75.7 mg, $5.0 \mathrm{~mol} \%$ ), initial pressure $0.5 \mathrm{MPa}, 120^{\circ} \mathrm{C}$. Yields and conversions are the average of two runs determined by GC using an internal standard technique. tained when the $\mathrm{Na}_{2} \mathrm{CO}_{3}$ loading was increased to $10.0 \mathrm{~mol} \%$, which indicated that $\mathrm{Na}_{2} \mathrm{CO}_{3}$ promoted the conversion of $\mathrm{PO}$. In the range of $\mathrm{Na}_{2} \mathrm{CO}_{3}$ loading from 1.5 to $10.0 \mathrm{~mol} \%$, the yields of DMC and PG increased with the increase of $\mathrm{Na}_{2} \mathrm{CO}_{3}$ loading, but the yield of PC decreased. The yield of PM decreased with the increase of $\mathrm{Na}_{2} \mathrm{CO}_{3}$ loading and remained roughly constant when the $\mathrm{Na}_{2} \mathrm{CO}_{3}$ loading was above 5.0 mol\%. $\mathrm{A} \mathrm{Na}_{2} \mathrm{CO}_{3}$ loading of $7.5 \mathrm{~mol} \%$ was selected for the one-pot synthesis of DMC.

\subsection{The effect of methanol amount on the synthesis of DMC}

The effect of methanol amount on the one-pot synthesis of DMC was tested using the same model reaction in the presence of $7.5 \mathrm{~mol} \% \mathrm{Na}_{2} \mathrm{CO}_{3}$ and the conditions of initial pressure 0.5 $\mathrm{MPa}, 120^{\circ} \mathrm{C}, 6 \mathrm{~h}$. The results are shown in Fig. 6 . A slight effect of methanol amount on the PO conversions was observed within the methanol amount range of 10 to 20 molar equivalents. When the methanol amount was increased from 5 to 15 molar equivalents, the yield of DMC increased from $33.5 \%$ to $45.6 \%$, and the yield of PC increased from $11.7 \%$ to $15.1 \%$. On further increasing the methanol amount to 20 molar equivalents, the yield of DMC decreased to $38.4 \%$. Therefore, the best amount of methanol was 15 molar equivalents in the present reaction.

\subsection{Scope and limitation of the substrates}

Using the optimized conditions, we further studied the generality of the one-pot synthesis of DMC using different epoxides. The reactions of ethylene oxide (A), styrene oxide (B), epichlorohydrin (C), glycidyl phenyl ether (D) and cyclohexene oxide (E) were investigated under the conditions of $120^{\circ} \mathrm{C}, 6 \mathrm{~h}$, $0.5 \mathrm{MPa}$. The results are summarized in Table 2. A and $\mathbf{B}$ exhibited efficient reactivity giving $63.5 \%$ and $59.0 \%$ yields of DMC, respectively (Table 2, entries 1 and 2). PO provided $45.6 \%$ yield of DMC (Table 2, entry 3). C, D and $\mathbf{E}$ gave 31\%-36\% yields of

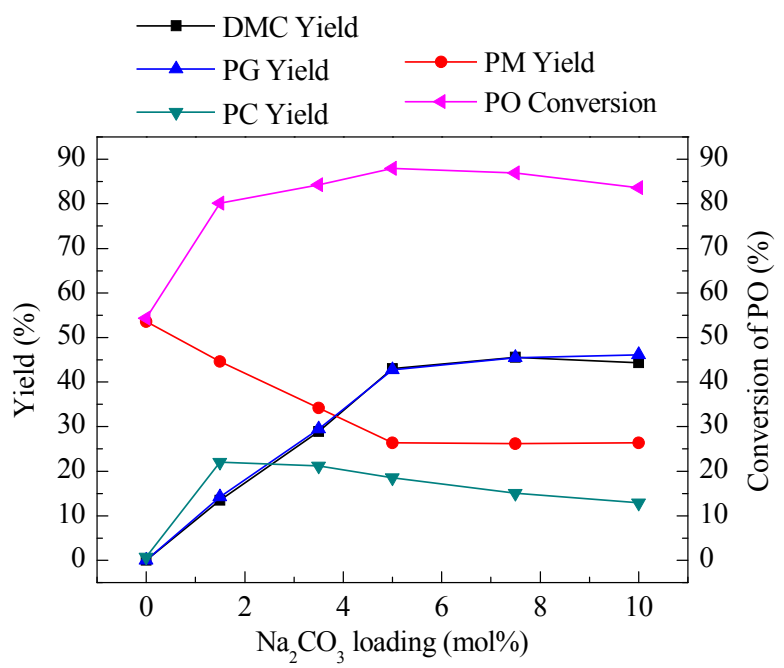

Fig. 5. Effect of $\mathrm{Na}_{2} \mathrm{CO}_{3}$ loading on the synthesis of DMC. Reaction conditions: $\mathrm{PO}(1 \mathrm{~mL}, 14.3 \mathrm{mmol}), \mathrm{CH}_{3} \mathrm{OH}(8.7 \mathrm{~mL}, 214.4 \mathrm{mmol})$, initial pressure $0.5 \mathrm{MPa}, 120^{\circ} \mathrm{C}, 6 \mathrm{~h}$. Yields and conversions are the average of two runs determined by GC using an internal standard technique. 


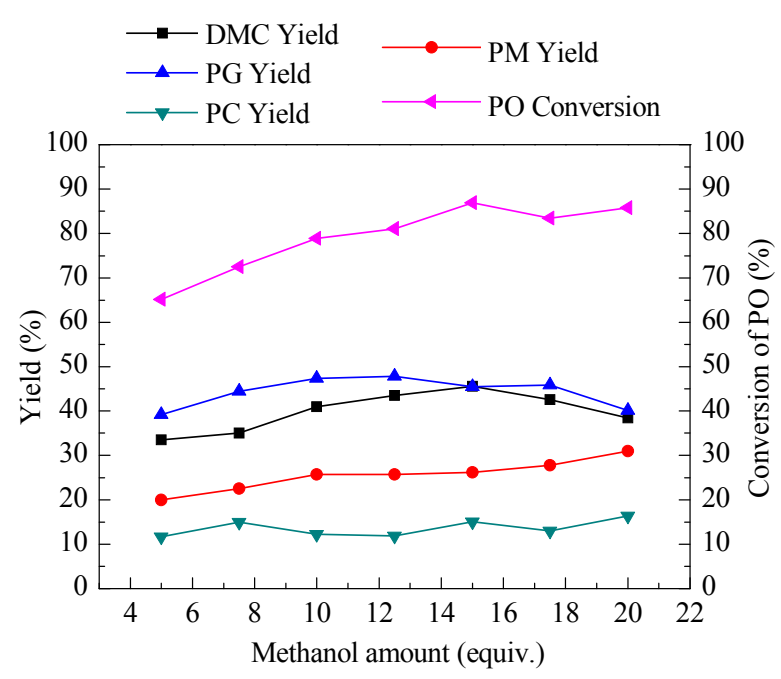

Fig. 6. Effect of methanol amount on the synthesis of DMC. Reaction conditions: $\mathrm{PO}(1 \mathrm{~mL}, 14.3 \mathrm{mmol}), \mathrm{Na}_{2} \mathrm{CO}_{3}(7.5 \mathrm{~mol} \%), 0.5 \mathrm{MPa}, 120^{\circ} \mathrm{C}$, $6 \mathrm{~h}$. Yields and conversions are the average of two runs determined by GC using an internal standard technique.

DMC. Hence, the order of reactivity for DMC formation under the same reaction conditions was $\mathbf{A}>\mathbf{B}>\mathrm{PO}>\mathbf{C}>\mathbf{D}>\mathbf{E}$.

\subsection{Possible mechanism}

Based on previous reports $[28,38,39]$ and the results presented above, a mechanism portraying the probable sequence of events is shown in Scheme 2. The $\mathrm{CO}_{3}{ }^{2-}$ group of the alkali carbonate attacks the carbon atom of the epoxide resulting in the ring opening of the epoxide (Step 1). Then, an interaction occurs between the oxygen anion and $\mathrm{CO}_{2}$, and an alkylcarbonate anion is formed (Step 2). Next, the alkylcarbonate anion is transformed into a cyclic carbonate (Step 3). Then methanol is activated by the carbonate anion to generate a hydrogen bond complex $\left(\mathrm{CH}_{3} \mathrm{OH} \cdots \mathrm{CO}_{3}{ }^{2-}\right)$ (Step 4$)$, which reacts with the cyclic carbonate to form an intermediate (Step 5), and DMC is

Table 2

Scope and limitation of the substrate

\begin{tabular}{lllc}
\hline Entry & Epoxide & Yield of DMC a (\%) \\
\hline 1 & (A) & 63.5 \\
6 & (B) & 59.0 \\
& (C) & 35.6 \\
\end{tabular}

Reaction conditions: Epoxide (14.3 mmol), $\mathrm{CH}_{3} \mathrm{OH}(8.7 \mathrm{~mL}, 214.4$ mmol), $\mathrm{Na}_{2} \mathrm{CO}_{3}$ (7.5 mol\%), initial pressure $0.5 \mathrm{MPa}, 120^{\circ} \mathrm{C}, 6 \mathrm{~h}$.

a Average of two runs determined by GC using an internal standard technique.

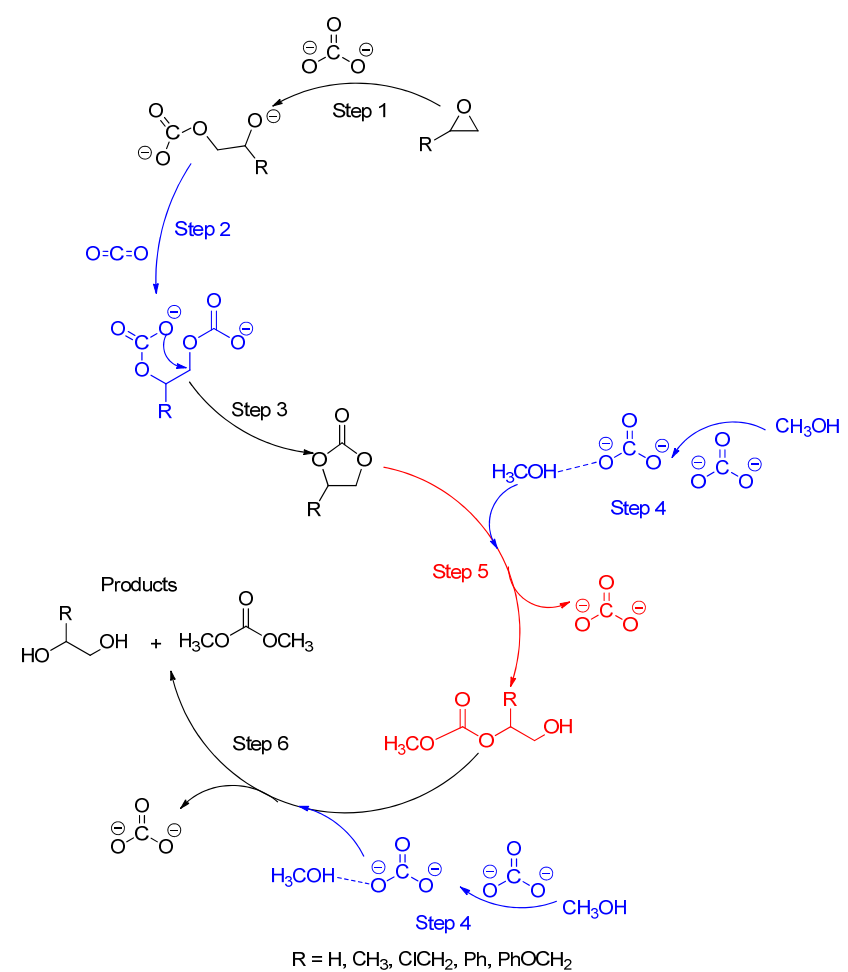

Scheme 2. Proposed mechanism for the one-pot synthesis of DMC.

subsequently produced (Step 6).

\section{Conclusions}

Alkali carbonate-catalyzed one-pot synthesis of DMC and 1,2-diols from epoxide, methanol, and $\mathrm{CO}_{2}$ was investigated. Under the optimized conditions of $120{ }^{\circ} \mathrm{C}$ and initial pressure of $0.5 \mathrm{MPa}, \mathrm{Na}_{2} \mathrm{CO}_{3}$ exhibited good catalytic activity and provided the highest DMC yield of $63.5 \%$ in $6 \mathrm{~h}$ with ethylene oxide. The results demonstrated that a low pressure is favorable for the one-pot synthesis of DMC.

\section{References}

[1] Winter R A.J Environ Econ Manag, 2014, 68: 124

[2] Altarawneh S, Behera S, Jena P, El-Kaderi H M. Chem Commun, 2014, 50: 3571

[3] Cox P M, Betts R A, Jones C D, Spall S A, Totterdell L I J. Nature, 2000, 408: 184

[4] Li Y H, Fang X J, Junge K, Beller M. Angew Chem Int Ed, 2013, 52 : 9658

[5] Wang Y B, Wang Y M, Zhang W Z, Lu X B. J Am Chem Soc, 2013, 135: 11996

[6] Wang Y B, Sun D S, Zhou H, Zhang W Z, Lu X B. Green Chem, 2013, 16: 2266

[7] Bates E D, Mayton R D, Ntai I, Davis J H. J Am Chem Soc, 2002, 124 : 926

[8] Wang J Q, Cheng W G, Sun J, Shi T Y, Zhang X P, Zhang S J. RSC Adv, 2014, 4: 2360

[9] Ma J, Han B X, Song J L, Hu J Y, Lu W J, Yang D Z, Zhang Z F, Jiang T, Hou M Q. Green Chem, 2013, 15: 1485

[10] Yang Z Z, He L N, Miao C X, Chanfreau S. Adv Synth Catal, 2010, 352: 2233 


\title{
Graphical Abstract
}

Chin. J. Catal., 2015, 36: 1136-1141 doi: 10.1016/S1872-2067(14)60309-0

Low pressure one-pot synthesis of dimethyl carbonate catalyzed by an alkali carbonate

Chun Liu*, Shaoke Zhang, Baoyi Cai, Zilin Jin

Dalian University of Technology

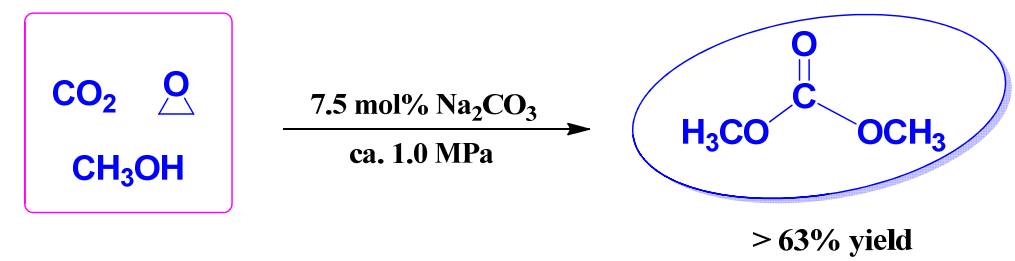

This work developed a protocol of alkali carbonate-catalyzed one-pot synthesis of dimethyl carbonate (DMC) from epoxide, $\mathrm{CO}_{2}$, and methanol. 63.5\% yield of DMC was achieved with an initial $\mathrm{CO}_{2}$ pressure of $0.5 \mathrm{MPa}$ and ethylene oxide as reactant.

[11] Song J L, Zhang Z F, Hu S Q, Wu T B, Jiang T, Han B X. Green Chem, 2009, 11: 1031

[12] Sakakura T, Choi J C, Yasuda H. Chem Rev, 2007, 107: 2365

[13] Gui X, Tang Z J, Fei W Y.J Chem Eng Data, 2010, 55: 3736

[14] Fu X L, Zhang Z, Li C M, Wang L B, Ji H Y, Yang Y, Zou T, Gao G H. Catal Commun, 2009, 10: 665

[15] Hood H P, Murdock H R.J Phys Chem, 1919, 23: 498

[16] Shaikh A A G, Sivaram S. Chem Rev, 1996, 96: 951

[17] Ono Y. Appl Catal A, 1997, 155: 133

[18] Wei T, Wang M H, Wei W, Sun Y H, Zhong B. Green Chem, 2003, 5: 343

[19] Choi J C, He L N, Yasuda H, Sakakura T. Green Chem, 2002, 4: 230

[20] Tian J S, Miao C X, Wang J Q, Cai F, Du Y, Zhao Y, He L N. Green Chem, 2007, 9: 566

[21] Tatsumi T, Watanabe Y, Koyano KA. Chem Commun, 1996: 2281

[22] Santos B A V, Pereira C S M, Silva V M T M, Loureiro J M, Rodrigues A E. Appl Catal A, 2013, 455: 219

[23] Yang Q S, Wang H, Ding X S, Yang X, Wang Y. Res Chem Intermed, 2013, DOI: $10.1007 / \mathrm{s} 11164-013-1514-4$.

[24] Xu W S, Ji S R, Quan W, Yu J Q. Modern Res Catal, 2013, 2: 22

[25] Yan C H, Lu B, Wang X G, Zhao J X, Cai Q H. J Chem Technol Biotechnol, 2011, 86: 1413

[26] Li J, Wang L G, Shi F, Liu S M, He Y D, Lu L J, Ma X Y, Deng Y Q. Catal Lett, 2010, 141: 339
[27] De C Y, Lu B, Lv H, Yu Y Y, Bai Y, Cai Q H. Catal Lett, 2008, 128: 459

[28] Tian J S, Wang J Q, Chen J Y, Fan J G, Cai F, He L N. Appl Catal A, 2006, 301: 215

[29] Chen X Z, Hu C W, Su J H, Yu T, Gao Z M. Chin J Catal (陈秀芝, 胡长 文, 苏俊华, 于涛, 高志明. 催化学报), 2006, 27: 485

[30] Li Y, Zhao X Q, Wang Y J. Appl Catal A, 2005, 279: 205

[31] Kishimoto Y, Ogawa I. Ind Eng Chem Res, 2004, 43: 8155

[32] Cui H Y, Wang T, Wang F J, Gu C R, Wang P L, Dai Y Y. Ind Eng Chem Res, 2004, 43: 7732

[33] Chang Y H, Jiang T, Han B X, Liu Z M, Wu W Z, Gao L, Li J C, Gao H X, Zhao G Y, Huang J. Appl Catal A, 2004, 263: 179

[34] Bhanage B M, Fujita S-i, Ikushima Y, Torii K, Arai M. Green Chem, 2003, 5: 71

[35] Cui H Y, Wang T, Wang F J, Gu C R, Wang P L, Dai Y Y. Ind Eng Chem Res, 2003, 42: 3865

[36] Bhanage B M, Fujita S I, Ikushima Y, Arai M. Appl Catal A, 2001, 219: 259

[37] Zhang W Y, Wang H, Li Q B, Dong Q N, Zhao N, Wei W, Sun Y H. Appl Catal A, 2005, 294: 188

[38] Sun J, Zhang S J, Cheng W G, Ren J Y. Tetrahedron Lett, 2008, 49: 3588

[39] Ju H Y, Manju M D, Kim K H, Park S W, Park D W. Korean J Chem Eng, 2007, 24: 917

\section{低压下碱金属碳酸盐催化一步法合成碳酸二甲酯}

\author{
刘 春, , 张绍科, 蔡宝仪, 金子林 \\ 大连理工大学精细化工国家重点实验室,辽宁大连116024
}

摘要: 报道了低压下碱金属碳酸盐催化环氧化物、 $\mathrm{CO}_{2}$ 和甲醇一步合成碳酸二甲酯(DMC)的方法, 系统考察了反应条件对一步合 成DMC的影响规律. 在最优反应条件下(初始压力 $0.5 \mathrm{MPa}$, 反应温度 $120^{\circ} \mathrm{C}$, 碳酸钠 $7.5 \mathrm{~mol} \%$ ), 以环氧乙烷为起始剂的DMC收率 达到 $63.5 \%$. 提出了碱金属碳酸盐催化一步法合成DMC的可能反应机理.

关键词: 碳酸二甲酯; 环氧化物; 碱金属碳酸盐; 一步法; 低压

收稿日期: 2015-01-07. 接受日期：2015-01-29. 出版日期: 2015-07-20.

*通讯联系人. 电话: (0411)84986182; 电子信箱: cliu@dlut.edu.cn

基金来源：中央高校基本科研业务费专项资金.

本文的英文电子版由Elsevier出版社在ScienceDirect上出版(http://www.sciencedirect.com/science/journal/18722067). 